\title{
Frequent Expression of CD10 and Bcl-6 in High-Grade Primary Extranodal Lymphoma with Diffuse Large B-cell Lymphoma Morphology
}

\author{
Yan-Chin, Tai, and Suat-Cheng, Peh
}

The distinction of de novo diffuse large B-cell lymphomas (DLBCL) from transformed MALT lymphomas is difficult in the absence of MALT-component. This study aims to study the phenotypic expression profiles of extranodal lymphomas, focusing on the characteristics of high-grade tumors. We categorized 52 extranodal B-cell lymphomas into Grade 1 (low-grade MALT lymphoma), Grade 2 (DLBCL with MALT component), and Grade 3 (DLBCL without MALT component) tumors based on histomorphology. There were 26 (50\%) Grade 1, 9 (17\%) Grade 2, 15 (29\%) Grade 3 tumors. We could not assess the grade of two tumors (4\%) due to limiting tumor tissues. The expression of $\mathrm{CD} 10, \mathrm{Bcl}-2, \mathrm{Bcl}-6$, and $\mathrm{p} 53$ was also investigated by immunohistochemistry. CD10 expression was present in one Grade 1 and six Grade 3 tumors. Bcl-6 expression was more common in high-grade tumors $(p=0.001)$, while Bcl-2 expression was associated with lower-grade tumors $(p=0.001)$. CD10 expression was more useful as a marker in distinguishing Grade 2 from Grade 3 tumors than Bcl-6 expression. p53 was more frequently expressed in high-grade tumors; the higher frequency of p53 expression in Grade 2 tumors may suggest a potential role in the transformation of Grade 1 to Grade 2 tumors.

Key words MALT lymphoma, DLBCL, CD10, Bcl-2, Bcl-6

\section{INTRODUCTION}

Extranodal lymphomas, commonly of the gastrointestinal tract, comprise of approximately $25 \%$ to $40 \%$ of non-Hodgkin's lymphomas (NHLs) ${ }^{1,2}$. Marginal zone B-cell lymphoma of mucosa-associated lymphoid tissue (MALT lymphoma) is the most common form, comprising up to $30 \%$ of extranodal lymphomas and accounting for $7 \%$ to $8 \%$ of total B-cell lymphomas ${ }^{1,3}$. Low-grade MALT lymphoma, which has been extensively described, exhibits prominent lymphoepithelial lesions and/or follicular colonization by small- to medium-sized centrocytelike cells ${ }^{1,2,4}$. These tumors can also often exhibit moderate cytological atypia of neoplastic lymphocytes and infiltrating plasma cells containing Dutcher's bodies ${ }^{1,2,4,5}$.

Received: Apr 22, 2004

Revised: May 28, 2004

Accepted: Jun 1, 2004

Department of Pathology, Faculty of Medicine, University of Malaya, Kuala Lumpur, Malaysia

Address correspondence and reprint request to Suat-Cheng Peh, Department of Pathology, Faculty of Medicine, University of Malaya, 50603 Kuala Lumpur, Malaysia
Although low-grade MALT lymphoma is regarded as clinically indolent, high-grade transformation is common ${ }^{6-8}$. Previous studies have reported that approximately $20 \%$ to $35 \%$ of gastric lymphomas are actually de novo diffuse large B-cell lymphomas $(\mathrm{DLBCL})^{9-11}$. The distinction of de novo DLBCL from transformed MALT lymphoma, however, is not possible in the vast majority of cases, due to the absence of MALT component ${ }^{5,12}$. Recent WHO classification stated that instead of using the term 'high-grade MALT lymphoma', all large B-cell lymphomas should be diagnosed as DLBCL, with only a reference to the presence or absence of MALT components ${ }^{1}$. As extranodal de novo DLBCL and transformed MALT lymphomas do not differ in either prognosis or overall survival, clinical studies support this decision. Individually, the outcome of these diseases is poorer than that observed for lowgrade MALT lymphoma, but significantly better than nodal DLBCL ${ }^{9-11,13}$.

Based on studies of the phenotypic expression and genotypic characteristics of the immunoglobulin gene in tumors, the normal counterpart of the neoplastic MALT lymphoma cells is postulated to be a post-germinal center marginal zone B-cel11,4,14,15. 
MALT lymphoma tumor cells lack specific markers, and are usually identified by exclusion ${ }^{1,2}$. The expression of CD10 and Bcl-6 appear to be reliable markers of germinal center derivation ${ }^{16-19}$; CD10 expression is also strongly associated with the $\mathrm{t}(14$; 18) translocation ${ }^{20,21}$. Hence, CD10 expression may help to distinguish the subset of de novo DLBCL derived from post-germinal center transformed MALT lymphomas. Rare cases of low-grade MALT lymphomas have been reported to express CDI0, which may further complicate difficulties distinguishing these lymphomas ${ }^{22-26}$. The expression of Bcl-6, however, was only reported in transformed MALT lymphomas, but not low-grade MALT lymphomas ${ }^{24,27-29}$. Hans et al. ${ }^{30}$ demonstrated that MUMI/IRF4 expression may be useful in differentiating Bcl-6 $6^{+}$germinal center cells $\left(\mathrm{MUM1}^{-}\right)$ from $\mathrm{Bcl}-6^{+}$cells that have not yet entered germinal centers $\left(\mathrm{MUMl}^{+}\right)$.

Bcl-2 protein is frequently expressed in lowgrade MALT lymphomas, but is absent from highgrade tumors $^{31-35}$. As Bcl-2 can block apoptosis to extend the survival of resting B-cells ${ }^{36}$, these cells can acquire secondary genetic changes over time that can result in progression to $\mathrm{DLBCL}^{35}$. The partial inactivation of $p 53$ through mutation or allelic loss may be associated with the development of lowgrade MALT lymphoma, while complete inactivation may contribute to transformation into a highgrade tumor ${ }^{6}$.

Even though extranodal de novo DLBCL and transformed MALT lymphomas do not differ in prognosis and overall survival, these diseases may represent distinct biological entities undergoing different lymphomagenic processes. This study aims to assess the efficacy of a panel of immunophenotype markers as a mechanism to differentiate low-grade MALT lymphomas, transformed MALT lymphomas, and extranodal de novo DLBCL.

\section{MATERIALS AND METHODS}

\section{Case Selection}

Fifty-two biopsies from 48 patients previously diagnosed with extranodal B-cell lymphomas over a period of 6 years, from 1994 to 1999, were retrieved from the archives of University of Malaya Medical Centre for the study. Clinical information was extracted from records volunteered by patients and attending clinicians. The tumors examined were taken from extranodal sites, with these sites being the only or most extensively affected locations. Patients with a previous history of nodal B-NHL were excluded from this study. Differential diagnoses excluded small-cell extranodal lymphomas, such as mantle cell lymphoma, small lymphocytic lymphoma, and follicular lymphoma by the absence of markers associated with those diseases according to previously established criteria: CD5 and cyclinD1 expression for mantle cell lymphoma, CD5 and CD23 expression for small lymphocytic lymphoma, and CD10 and Bcl-6 expression for follicular lymphoma ${ }^{1,2,4,12}$.

\section{Histological Grading}

Tumors were sub-classified as low-grade MALT lymphoma (Grade 1), DLBCL with evidence of transformed MALT lymphoma (Grade 2), and DLBCL without any evidence of MALT component/de novo DLBCL (Grade 3), according to the histological system proposed by Isaacson ${ }^{4}$. The categorization of low-grade MALT lymphoma was based on histomorphological features $\left.{ }^{1}: 1\right)$ dense infiltration of small- to medium-sized centrocyticlike cells with irregular nuclei and relatively abundant pale cytoplasm, 2) the accumulation of infiltrating centrocyte-like cells in the epithelium leading to destruction, forming a lymphoepithelial lesion, 3 ) the presence of reactive follicles that may be infiltrated by centrocyte-like cells, leading to follicular colonization, 4) presence of transformed centroblast- or immunoblast-like cells, and 5 ) extensive plasma cell differentiation. A tumor was considered to be high-grade DLBCL when the tumor cells were large, centroblast- or immunoblast-like, and present in compact or sheet-like proliferative foci.

\section{Immunophenotyping and analysis}

Immunoperoxidase staining of $4-\mu \mathrm{m}$-thick paraffin sections utilized the Avidin-Biotin Complex (ABC) system (DakoCytomation, Glostrup, Denmark), StrepABC system (DakoCytomation), and the indirect two-step detection system, EnVision $+{ }^{\mathrm{TM}}$ (DakoCytomation). Antigen retrieval was performed accordingly by the microwave heat-inducing method, pressure-cooking, or trypsin digestion. The tissues were stained with a panel of antibodies against lymphoid markers. Antibodies against CD20 (L26), CD3, CD21 (clone 1F8), Bcl-2 (clone 124), Bcl-6 (clone PG-B6p), and p53 (clone DO-7) 
were obtained from DakoCytomation. Antibodies specific for CD5 (NCL-5), CD10 (NCL-CD10-270), CD23 (NCL-Cd23-1B12), CD35 (NCL-CD35), and cyclinD1 (NCL-CYCLIN D1-GM) were purchased from Novocastra (Newcastle upon Tyne, UK). An anti-IRF-4 antibody (clone sc-11450) was acquired from Santa Cruz Biotechnology (CA, USA). Antibody staining was visualized using the liquid $\mathrm{DAB}^{+}$ substrate-chromogen system (DakoCytomation). Tissues were lightly counterstained with hematoxylin.

Estimation of the numbers of tumor cells expressing p53 protein classified the tumors into the following categories: $<10 \%$ (negative), $10-25 \%$ (low), 25-50\% (moderate), $\geq 50 \%$ (high).

Follicular colonization was assessed with the aid of immunostaining for CD21, CD23, CD 35, CD10, Bcl-2, and Bcl-6. CD21, CD23, and CD35 identify follicles through staining of follicular dendritic cell networks. B cells present within reactive germinal centers are typically $\mathrm{CD} 10^{+} / \mathrm{Bcl}-6^{+} / \mathrm{Bcl}-2^{-}$. During follicular colonization, $\mathrm{CD}^{+} 0^{+} / \mathrm{Bcl}^{-} 6^{+}$germinal center cells were replaced by infiltrating bcl-2+ tumor cells $\left(\mathrm{CD} 10^{-} / \mathrm{Bcl}-6^{-} / \mathrm{Bcl}-2^{+}\right)$.

\section{Statistical Analysis}

Statistical analysis was performed by using the Pearson $\chi^{2}$ test (SPSS for Windows) with a 95\% confidence interval.

\section{RESULTS}

\section{Case Data}

This study included 48 patients, four of which had two biopsies each, giving a total of 52 biopsies. These 48 patients, 26 males (54\%) and 22 females (46\%), ranged in age from 20 to 87 years, with a mean and median of 58 and 62 years, respectively. The age of one (2\%) patient was not available from the clinical records. Of the 52 biopsies, 42 (81\%) were from the gastrointestinal tract. Thirty-two of these were from the stomach, three were from the small intestine, two each were from the duodenum, colon, and caecum, and one from the rectum. The remaining $10(20 \%)$ biopsies were from the orbit (4), thyroid (2), subconjunctival mass (1), tongue (1), lung (1), and cheek muscle (1).

\section{Histological Grade}

Of the 52 biopsies, 26 (50\%) were categorized as Grade 1 (Fig. 1a), 9 (17\%) were determined to be Grade 2 (Fig. 1b), and 15 (29\%) were classified as Grade 3 tumors (Fig. 1c). The grade of two (4\%) gastric biopsies could not be determined due to limited amounts of tumor tissue. The tumors of the gastrointestinal tract were divided into 18 (43\%) Grade 1, 9 (21\%) Grade 2, and 13 (31\%) Grade 3 tumors. We could not observe a correlation between histological grade and site of presentation within the gastrointestinal tract $(p=0.204)$. All biopsies from other sites were determined to be Grade $1(8 / 10$, $80 \%)$ tumors, with the exception of the tongue and thyroid samples that were both Grade $3(2 / 10,20 \%)$ tumors. Lymphoepithelial lesions were observed in $13 / 26(50 \%)$ Grade 1 tumors and 3/9 (33\%) of Grade 2 tumors. Of the Grade 1 tumors, lymphoepithelial lesions were found in $11 / 18(61 \%)$ of gastrointestinal tract samples, in contrast to $2 / 8$ (25\%) from other extranodal sites.

\section{Immunophenotype Pattern}

While all of the tumors expressed CD20, we could not observe CD5, CD23 and cyclinD1 expression in any samples. CD10 and Bcl-6 were expressed in seven and 14 tumors, respectively. Of these tumors, CD10 and Bcl-6 were co-expressed in three tumors. CD10 and Bcl-6 expressions according to histological grade are summarized in Table 1. Of the $11 \mathrm{CD} 10^{-} / \mathrm{Bcl}_{-} 6^{+}$tumors, five (45\%) expressed IRF4 (one Grade 2 and four Grade 3 tumors). All $\mathrm{CD} 10^{+}$tumors were classified as Grade 3, with the exception of one Grade 1 tumor, indicating a significant $(p=0.005)$ association of CD10 expression with higher-grade classification. In contrast, CD10 expression was not associated with an origin within the gastrointestinal tract $(p=0.165)$. The $\mathrm{CDI}^{+}$ Grade 1 tumor contained prominent lymphoepithelial lesions (Fig. 2a). Within this sample, while CD10 was expressed in almost all tumor cells (Fig. 2b), Bcl-6 was expressed sporadically in scattered blasts (Fig. 2c), in contrast to the intense staining seen throughout Grade 3 tumors (Fig. 2d).

Bcl-6 protein was expressed in 2/26 (8\%) Grade 1 (including the biopsy co-expressing CD10), 4/8 (50\%) Grade 2, and 8/13 (61\%) Grade 3 tumors. The reactivity of Bcl-6 staining in 4 biopsies could not be determined due to technical problems. The expression of Bcl-6 protein was significantly associated 


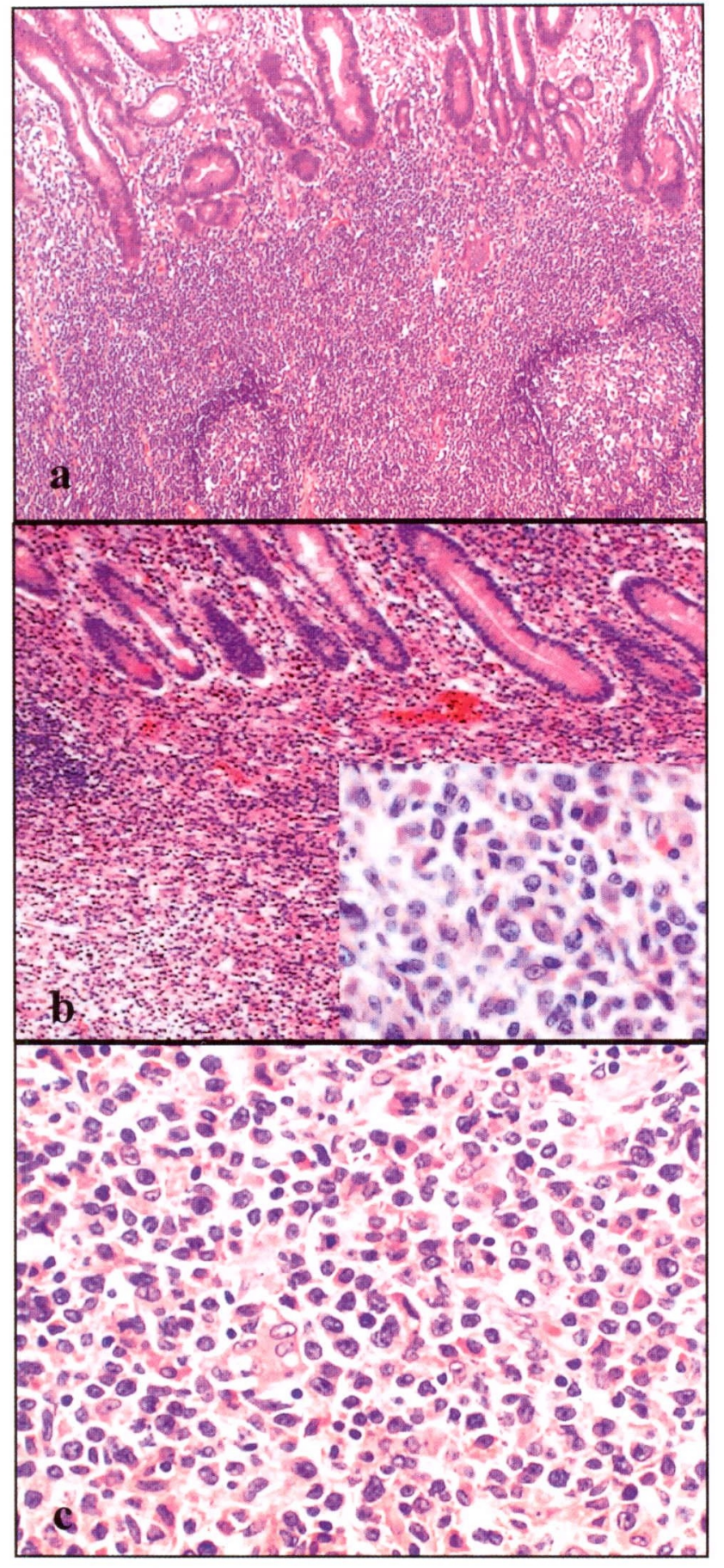

Fig. 1. Histological features of tumors of different histological grades. a) A low-grade MALT lymphoma (Grade 1 tumor) demonstrated the infiltration of centrocyte-like cells and the presence of reactive lymphoid follicles $(\mathrm{H} \& \mathrm{E}, \times 55)$. b) A diffuse large B-cell lymphoma contained a MALT component (H\& $\mathrm{E}, \times 55$ ) (insert, $\mathrm{H} \& \mathrm{E}, \times 325$ ) (Grade 2 tumor). c) A diffuse large B-cell lymphoma lacking a MALT component (Grade 3 tumor) exhibited the diffuse infiltration of large cells $(\mathrm{H} \& \mathrm{E}, \times 325)$. with higher grade tumors (Grade 2 and Grade 3) $(p=0.001)$, but not with CDl0 expression $(p=$ $0.480)$. Bcl-6 was not associated with tumor origin within the gastrointestinal tract $(p=0.454)$.

$\mathrm{Bcl}-2$ protein was expressed by the tumor cells in $30 / 52$ (58\%) biopsies, including 21/26 (81\%) Grade 1, 4/9 (44\%) Grade 2, $3 / 15$ (20\%) Grade 3 tumors, and $2 / 2(100 \%)$ tumors that could not be histologically assessed. While significantly associated with Grade 1 tumors $(p=0.001)$, Bcl-2 expression exhibited an inverse association with CD10 expression $(p=0.012)$; only one Grade 3 tumor coexpressed CD10 and bcl-2. Bcl-2 expression in tumors of the gastrointestinal tract did not differ from those in other extranodal sites $(p=0.102)$.

The follicular dendritic cell network was visualized by staining with anti-CD21 (Fig. 3a), antiCD23, and anti-CD35 (Fig. 3b) antibodies in 28, 18, and 31 of the total biopsies, respectively. Follicular colonization (Fig. 3c \& 3d) was observed in 19/26 (73\%) Grade 1 and $2 / 9$ (22\%) Grade 2 tumors Reactive lymphoid follicles were detected in $22 / 26$ (85\%) Grade 1, 4/9 (44\%) Grade 2, and 2/15 (13\%) Grade 3 tumors. Reactive lymphoid follicles correlated significantly with Grade 1 tumors $(p<0.001)$.

The majority of samples expressed p 53 protein in less than $10 \%$ of the total tumor cells $(35 / 51,67 \%)$. One biopsy was not reactive for p53 immunostaining. Of the Grade 1 tumors, only one each exhibited moderate and high levels of $\mathrm{p} 53$ protein expression. Only five (10\%) biopsies expressed p53 protein in ? $50 \%$ of the tumor cells. p53 expression was not associated with Bcl-2 expression $(p=0.461)$.

\section{DISCUSSION}

MALT lymphomas exhibit a spectrum of morphological characteristics, ranging from low-grade tumors that resemble benign Helicobacter pyloriassociated gastritis to high-grade tumors resembling nodal DLBCL. Chronic gastritis and low-grade MALT lymphoma share many features, including the presence of centrocytic-like cells, reactive follicles, and small lymphocytes infiltrating the lamina propria and epithelium ${ }^{37}$. Thus, distinguishing these conditions remains a challenge in some cases ${ }^{38}$. While prominent lymphoepithelial lesions serve as a conclusive criterion separating neoplastic from reactive proliferation, this feature was only found in $48 \%$ and $38 \%$ of Grade 1 and Grade 2 tumors in the current series, respectively. This result is in agreement with previous reports, in which lymphoepith- 
Table 1 CD10 and Bcl-6 expression in tumors of different histological grades

\begin{tabular}{|c|c|c|c|c|c|}
\hline & $\begin{array}{l}\text { Histological } \\
\text { Grade }\end{array}$ & $\begin{array}{l}\mathrm{CD}^{+0^{+\dagger}} / \\
\mathrm{Bcl}-6^{+\ddagger}\end{array}$ & $\begin{array}{l}\mathrm{CD}^{-} 0^{+} / \\
\mathrm{Bcl}-6^{-}\end{array}$ & $\begin{array}{c}\mathrm{CD}^{-} 0^{-} / \\
\mathrm{Bcl}_{-} 6^{+}\end{array}$ & $\begin{array}{l}\mathrm{CDI0}^{-} \\
\mathrm{Bcl}-6^{-*}\end{array}$ \\
\hline & 1 & 1 & 0 & 1 & 24 \\
\hline & 2 & 0 & 0 & 4 & 4 \\
\hline & 3 & 2 & 4 & 6 & 1 \\
\hline & NA & 0 & 0 & 0 & 1 \\
\hline & Total & 3 & 4 & 11 & 30 \\
\hline$\dagger$ & \multicolumn{5}{|c|}{ CDI0 expression was associated with Grade 3 tumors $(p=0.005)$} \\
\hline$\ddagger$ & \multicolumn{5}{|c|}{ Bcl-6 expression was associated with high-grade tumors $(p=0.001)$} \\
\hline$*$ & \multicolumn{5}{|c|}{ Excluded four biopsies that were not reactive for $\mathrm{Bcl}-6$ staining } \\
\hline NA & \multicolumn{5}{|c|}{ Not histologically assessable } \\
\hline$\hat{\imath}$ & \multicolumn{5}{|c|}{ One Grade 2 and four Grade 3 tumors expressed MUM1/IRF4 protein } \\
\hline
\end{tabular}
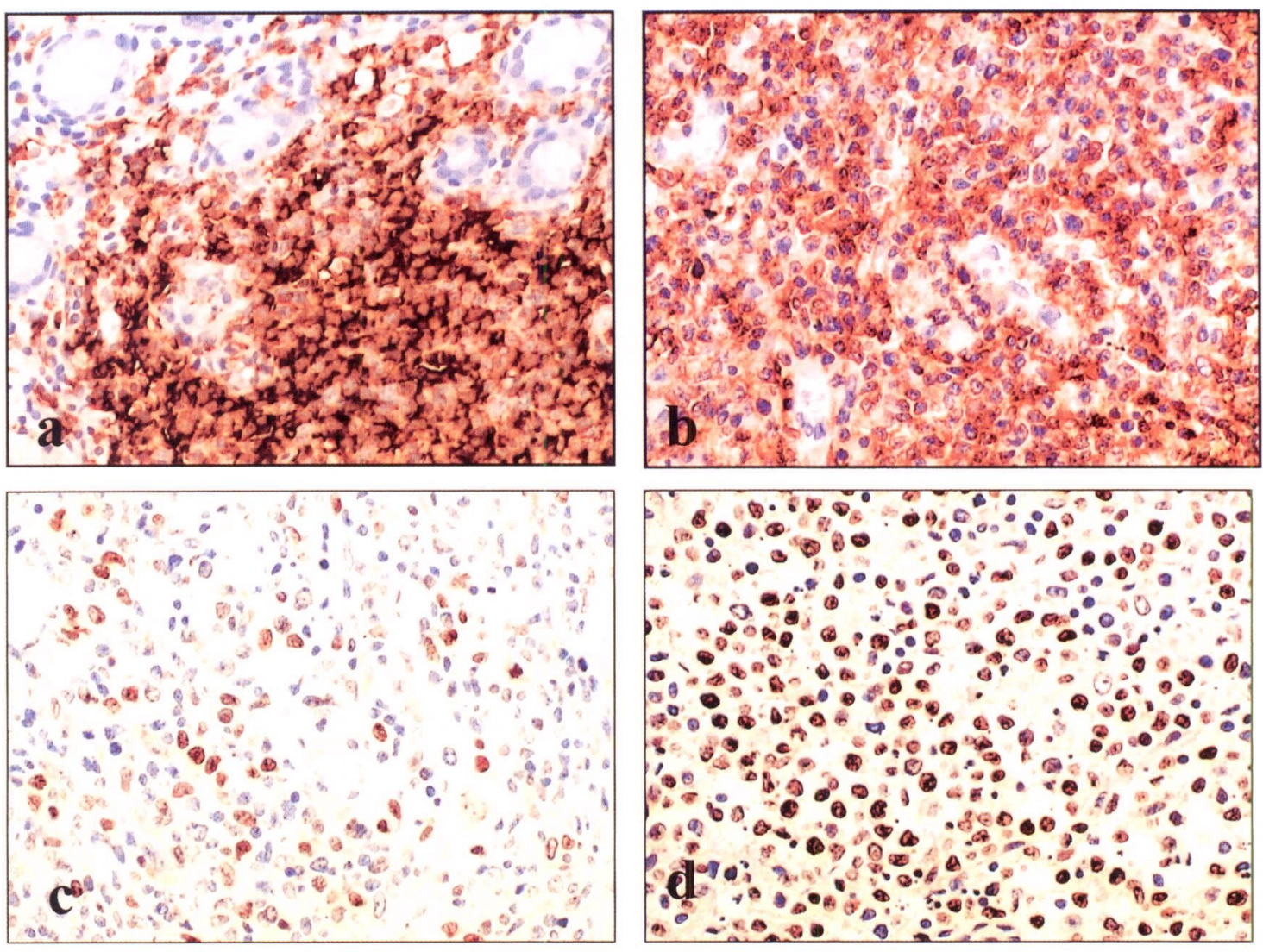

Fig. 2. Immunostaining of a $\mathrm{CD} 10^{+} / \mathrm{Bcl}-6^{+}$low-grade MALT lymphoma $(\mathrm{a}-\mathrm{c})$ and a Grade 3 tumor (d). a) $\mathrm{CD}_{20} 0^{+} \mathrm{B}$-cells were observed infiltrating the epithelium, forming the characteristic lymphoepithelial lesion $($ CD20 immunostain, $\times 280)$. b) Almost all tumor cells expressed CD10 (CD10 immunostain, $\times 280$ ). c) Bcl-6 was expressed sporadically by scattered blasts (Bcl-6 immunostain, $X$ 280). d) A Grade 3 tumor sample exhibited diffusely intense staining for Bcl-6 (Bcl-6 immunostain, $X$ 280). 


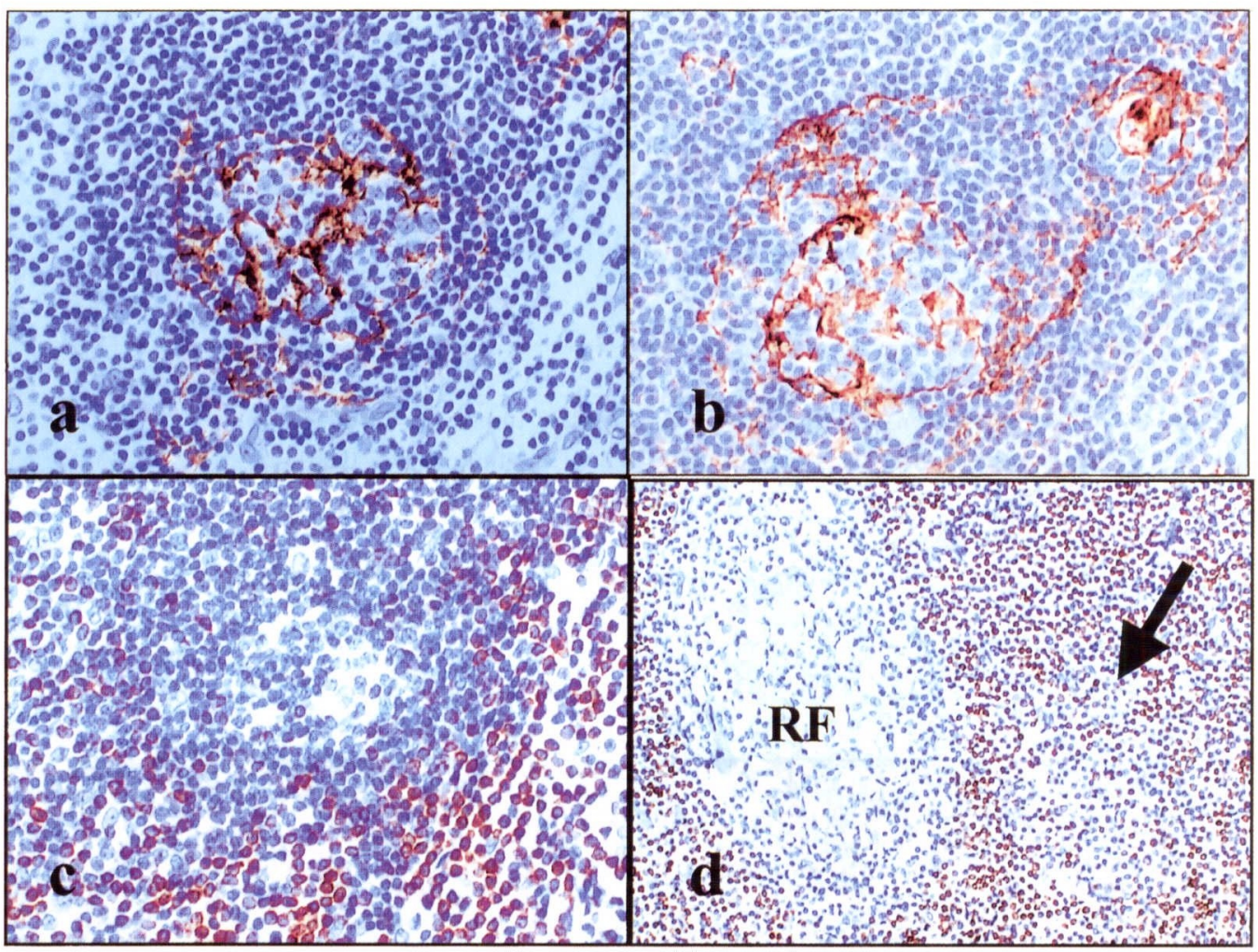

Fig. 3. The follicular dendritic cell network and follicular colonization as visualized by immunstaining. The follicular dendritic cell network in a Grade 1 tumor (Case 2) was demonstrated by a) CD21 (CD21 immunostaining, $\times 260)$ and b) CD35 (CD35 immunostaining, $\times 260$ ) staining. c) Bcl-2 staining of the same follicles in (a) \& (b) demonstrated the infiltration of tumor cells into the follicles (Bcl-2 immunostaining, $\times 260$ ). d) An additional Grade 1 tumor exhibited $\mathrm{Bcl}-2^{+}$centrocyte-like cells infiltrating the reactive follicles, indicated by the black arrow, while the adjacent reactive follicle (RF) is devoid of $\mathrm{Bcl}-2^{+}$cells (Bcl-2 immunostaining, $\times 135$ ).

Table 2 Bcl-2 and p53 expression according to the histological grades

\begin{tabular}{|c|c|c|c|c|c|}
\hline \multirow{2}{*}{$\begin{array}{c}\text { Histological } \\
\text { Grades }\end{array}$} & \multirow[b]{2}{*}{$\mathrm{Bcl}-2^{*}$} & \multicolumn{4}{|c|}{$\mathrm{p} 53^{* *}$} \\
\hline & & $\begin{array}{c}<10 \% \\
\text { (Negative) }\end{array}$ & $\begin{array}{c}10 \%-25 \% \\
\text { (Low) }\end{array}$ & $\begin{array}{c}25 \%-50 \% \\
\text { (Moderate) }\end{array}$ & $\begin{array}{l}>50 \% \\
\text { (High) }\end{array}$ \\
\hline Grade 1 & $21 / 26$ & $20 / 26$ & $4 / 26$ & $1 / 26$ & $1 / 26$ \\
\hline Grade 2 & $4 / 9$ & $5 / 8$ & $0 / 8$ & $1 / 8$ & $2 / 8$ \\
\hline Grade 3 & $3 / 15$ & $10 / 15$ & $2 / 15$ & $1 / 15$ & $2 / 15$ \\
\hline NA & $2 / 2$ & $0 / 2$ & $2 / 2$ & $0 / 2$ & $0 / 2$ \\
\hline
\end{tabular}

* Bcl-2 expression was significantly associated with Grade 1 tumors $(p=0.001)$

** One biopsy was not reactive for p53 immunostaining

elial lesions were only observed in one third of the cases $^{5,12}$. As lymphoepithelial lesions may be missed due to limiting quantities of tissues evaluated, $\mathrm{Zu}$ kerberg et $a l^{5}$ suggested that sufficient sampling of the biopsies is essential to detect these lesions. Lymphoepithelial lesions were rarely observed in non-gastric Grade 1 tumors. The presence of centrocytic-like cells and germinal center surface markers were the most consistent features observed in Grade 1 tumors. Positive staining for markers characteristic of germinal centers, found in $85 \%$ of examined tumors, was also significantly associated 
with low-grade MALT lymphoma.

Transformation of low-grade MALT lymphomas into higher-grade tumors is signified by the emergence of increasing numbers of blasts and the formation of sheet-like blast clusters ${ }^{4,7,8,39,40}$. It is almost impossible to differentiate Grade 2 from Grade 3 tumors in the absence of a MALT component. The potential for MALT component to be missed in small biopsies ${ }^{41,42}$ further complicates the differentiation of Grade 2 and Grade 3 tumors. Chan $^{2}$ noted that gastric DLBCL, regardless of the presence or absence of a MALT component, exhibited an increased frequency of $c-m y c$ gene rearrangement (50\%) and reduced frequency of Bcl-2 expression from the levels observed in the equivalent nodal DLBCL. Grade 2 and Grade 3 tumors do not differ clinically in their prognosis and overall survival ${ }^{9-11,13}$. Cogliatti et al. ${ }^{10}$ reported that the 5-year survival for extranodal DLBCL was significantly worse than that seen for Grade 1 tumors.

Even though the histological features do not support the separation of Grade 2 and Grade 3 tumors, the immunophenotypic profiles do exhibit differences in expression profiles. Grade 2 tumors were more similar to Grade 1 tumors, with a notable absence of CD10 expression. Grade 1 and Grade 2 tumors displayed a general immunophenotypic profile of $\mathrm{CD} 20^{+} / \mathrm{CD}^{-} / \mathrm{CyclinD} 1^{-} / \mathrm{CD} 10^{-} / \mathrm{CD}^{-} 3^{-} /$ $\mathrm{CD} 21^{-}$. While none of the Grade 2 tumors expressed CD10, 47\% of the Grade 3 tumors expressed this marker. Statistical analysis demonstrated that the increased incidence of CD10 expression in Grade 3 tumors was significant. This result suggests the possibility that a substantial proportion of these Grade 3 tumors were not derived from low-grade MALT lymphomas. These $\mathrm{CD} 10^{+}$Grade 3 tumors were more likely de novo extranodal DLBCL derived from germinal centers, as reported by previous studies $^{9-11}$. We cannot confirm, however, that the CD 10- Grade 3 tumors were derived from MALT lymphomas, as nodal DLBCL transformed from follicular lymphomas also tend to lose CD10 expres$\operatorname{sion}^{43}$. Moreover, CD10 expression is only reported in $20 \%$ to $30 \%$ of nodal DLBCL ${ }^{43,44}$.

Although CD10 is reportedly a reliable marker for germinal center derivation ${ }^{16-19}$, it can be expressed in rare cases of B-cell marginal zone lymphomas ${ }^{22-26}$. In this study, we observed one CD $10^{+}$Grade 1 tumor with prominent lymphoepithelial lesions, small- to medium-sized centrocytic-like cells, and few blasts. Our observation agrees with at least four additional reports that rare Grade 1 tumors can express $\mathrm{CD} 10^{22,23,25,26}$. In addition, Kwon et al. ${ }^{24}$ reported the expression of CD10 in 3/20 of the examined Grade 2 (high-grade MALT lymphoma) tumors.

Bcl-6 protein expression has been reported in both germinal center-derived cells ${ }^{16,17,19}$ and nongerminal center cells ${ }^{19}$. Tumor cells of true germinal center derivation exhibit an intense diffuse expression pattern, in comparison to the sporadic expression seen in non-germinal center cells ${ }^{19,24}$. The sporadic Bcl-6 expression pattern observed in the $\mathrm{CD} 10^{+}$Grade 1 tumor was similar to the pattern described by Ree et al. ${ }^{19}$ and Kwon et al. ${ }^{24}$. Blasts expressing Bcl-6 in this Grade 1 tumor may be residual reactive follicle center cells that have been trapped within the tumor ${ }^{16,24}$. Takeshita et al. ${ }^{45}$ suggested that de-differentiation or re-entry of tumor cells into germinal centers during follicular colonization may reactivate Bcl-6 protein expression, resulting in rare $\mathrm{Bcl}-6^{+}$marginal zone B-cells. The remaining two cases of Grade 3 tumors co-expressing $\mathrm{CD} 10$ and Bcl-6, in which intense expression of Bcl6 was observed in nearly all tumor cells, are likely to represent tumors of germinal center derivation. In

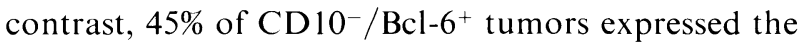
MUM1/IRF4 protein, indicating derivation from activated B-cells ${ }^{30}$. Chang et al. ${ }^{46}$ suggested that these tumor cells may represent a third group of DLBCL derived from activated germinal center B-cells. This hypothesis may not be true for a subset of Grade 2 tumors, as MUMl/IRF4 expression has also been shown in $42 \%$ of extranodal marginal zone lymphomas ${ }^{47}$. The expression of Bcl-6 by the subjects in this report agreed with previous studies; high expression levels were only observed in highgrade DLBCL, regardless of MALT component ${ }^{27,28,48}$. Bcl-6 protein expression may be associated with the high-grade transformation of low-grade MALT lymphomas ${ }^{27}$.

We observed a decreasing frequency of $\mathrm{Bcl}-2$ expression in high-grade tumors, concurring with previous studies that demonstrate the loss of $\mathrm{Bcl}-2$ protein upon progression of low-grade MALT lymphomas into high-grade tumors ${ }^{31-35}$. The frequent expression of $\mathrm{Bcl}-2$ in low-grade MALT lymphomas suggest that this protein plays an important role in lymphomagenesis, potentially acting through its ability to block apoptosis ${ }^{31-33,35}$. Escape from apoptosis increases the incidence of other genetic abnormalities that may ultimately lead to neoplastic transformation. The expression of Bcl-2 protein does not define neoplastic low-grade MALT 
lymphoma, as this molecule is frequently expressed by hyperplastic marginal zone cells ${ }^{49}$. Although the role of Bcl-2 in the lymphomagenesis of MALT lymphomas requires further investigation, the increased expression in low-grade tumors may simply reflect the intact regulation of $\mathrm{Bcl}-2$ in cells derived from such marginal zone B-cells. In this study, the frequency of $\mathrm{Bcl}-2$ expression was significantly lower in high-grade DLBCL than in low-grade MALT lymphomas. It is also plausible that, as tumors progress acquire high-grade character, additional genetic abnormalities may abrogate the need for Bcl-2 in tumor survival ${ }^{33,35,50}$.

Higher levels of p53 expression $(\geq 50 \%)$ were observed in Grade 2 tumors (25\%) in comparison to the levels seen in Grade 1 (4\%) and Grade 3 (13\%) tumors. Higher p53 protein expression in Grade 2 tumors suggests that the mutation of the $p 53$ gene may play a role in the transformation of low-grade to high-grade MALT lymphomas. This possibility is supported by molecular evidence that genetic inactivation of $p 53$ is important for the transformation of low-grade MALT lymphomas into highgrade tumor ${ }^{6}$. According to Stefanaki et al. ${ }^{51}$, mutation of p53 gene was detected in 33\% of Grade 2 tumors, in comparison to $19 \%$ of Grade 1 tumors. All Grade 2 tumors with positive p53 immunostaining contained missense mutations of the p53 gene. Therefore, it is speculated that mutation of $p 53$ gene may be required for the transformation of the lowgrade MALT lymphomas into high-grade tumor. The expression of p53 protein in Grade 3 tumors was in agreement with reports of nodal DLBCL (17\% to $40 \%)^{13,52}$.

In conclusion, the diagnosis of low-grade MALT lymphoma requires a combination of histomorphological and immunophenotypic characteristics. Although rare cases of low-grade MALT lymphoma have been reported to express an aberrant immunophenotype, including markers such as CD5 and CD10, this lymphoma typically expresses an immunophenotype of $\mathrm{CD} 20^{+} / \mathrm{CD}^{-} / \mathrm{CD}^{-} /$ cyclinD $1^{-} / \mathrm{CD}_{10}-/ \mathrm{CD} 23^{-}$. CD10 expression is useful to differentiate between Grade 3 and Grade 2 tumors, while bcl-6 expression is correlated with high-grade tumors. Bcl-2 protein is frequently expressed in low-grade tumors, but is usually lost in high-grade tumors. The pattern of p53 protein expression suggests that mutation of the $p 53$ gene may function in the transformation of low-grade MALT lymphomas into high-grade tumor.

\section{ACKNOWLEDGMENT}

This study was supported by the Ministry of Science, Technology, and Environment, Malaysia (IRPA 06-02-03-1014), and the Malaysia Toray Science Foundation (Science \& Technology Research Grant MTSF103.0.8123211) as work contributing to a Masters degree in Medical Science, University of Malaysia, for Tai YC.

\section{REFERENCES}

1 Jaffe ES, Harris NL, Stein H, Vardiman JW (eds) : World Health Organization classification of tumours: Pathology and genetics of tumours of haematopoietic and lymphoid tissues. Lyon, IARC Press, 2001.

2 Chan JKC: Gastrointestinal lymphomas: an overview with emphasis on new findings and diagnostic problems. Sem Diagn Pathol 13: 260-296, 1996.

3 Gospodarowicz MK, Sutcliffe SB: The extranodal lymphomas. Semin Radiat Oncol 5: 281-300, 1995.

4 Isaacson PG: Gastrointestinal lymphoma. Hum Pathol 25: 1020-1029, 1994.

5 Zukerberg LR, Ferry JA, Southern JF, Harris NL: Lymphoid infiltrates of the stomach : evaluation of histologic criteria for the diagnosis of low-grade gastric lymphoma on endoscopic biopsy specimens. Am J Surg Pathol 14: 1087-1099, 1990.

6 Du M, Peng H, Singh N, Isaacson PG, Pan L: The accumulation of p53 abnormalities is associated with progression of mucosa-associated lymphoid tissue lymphoma. Blood 86: 4587-4593, 1995.

7 Montalban C, Manzanal A, Castrillo JM, Escribano L, Bellas C: Low grade gastric B-cell MALT lymphoma progressing into high grade lymphoma. Clonal identity of the two stages of the tumour, unusual bone involvement and leukemic dissemination. Histopathology 27 : 89-91, 1995.

8 Peng $\mathrm{H}$, Du M, Diss TC, Isaacson PG, Pan L: Genetic evidence for a clonal link between low adn high-grade components in gastric MALT B-cell lymphoma. Histopathology 30: 425-429, 1997.

9 Hiyama T, Haruma K, Kitadai Y, Masuda H, Miyamoto M, Ito M, Kamada T, Tanaka S, Uemura N, Yoshihara M, Sumii K, Shimamoto F, Chayama $\mathrm{K}$ : Clinicopathological features of gastric mucosaassociated lymphoid tissue lymphoma: A comparison with diffuse large B-cell lymphoma without a mucosa-associated lymphoid tissue lymphoma component. J Gastroenterol Hepatol 16: 734-739, 2001.

10 Cogliatti SB, Schmid U, Schumacher U, Eckert F, Hansmann ML, Hedderich J, Takahashi H, Lennert $\mathrm{K}$ : Primary B-cell gastric lymphoma : a 
clinicopathological study of 145 patients. Gastroenterology 101: 1159-1170, 1991.

11 Nakamura S, Akazawa K, Yao T, Tsuneyoshi M : Primary gastric lymphoma, a clinicopathologic study of 233 cases with special reference to evaluation with the MIB-1 index. Cancer 76: 1313-1324, 1995.

12 Zucca E, Roggero E, Pileri S: B-cell lymphoma of MALT type: a review with special emphasis on diagnostic and management problems of low-grade gastric tumours. Br J Haematol 100: 3-14, 1998.

13 Kramer MHH, Hermans J, Wijburg E, Philippo K, Geelen E, van Krieken JHJM, de Jong D, Maartense E, Schuuring E, Kluin PM : Clinical relevance of BCL2, BCL6, and MYC rearrangements in diffuse large B-cell lymphoma. Blood 92: 3152-3162, 1998.

14 Qin Y, Greiner A, Trunk MJF : Somatic hypermutation in low-grade mucosa-assocaited lymphoid tissue-type B-cell lymphoma. Blood 86 : 3528-3534, 1995.

15 Bahler DW, Miklos JA, Swerdlow SH : Ongoing Ig gene hypermutation in salivary gland mucosaassociated lymphoid tissue-type lymphomas. Blood 89: 3335-3344, 1997.

16 Dogan A, Bagdi E, Munson P, Isaacson PG : CD10 and BCL-6 expression in paraffin sections of normal lymphoid tissue and B-cell lymphomas. Am J Surg Pathol 24: 846-852, 2000.

17 Flenghi L, Bigerna B, Fizzotti M, Venturi S, Pasqualucci L, Pileri S, Ye BH, Gambacorta M, Pacini R, Baroni CD, Pescarmona E, Anagnostopoulos I, Stein H, Asdrubali G, Martelli MF, Pelicci P, Dalla-Favera R, Falini B: Monoclonal antibodies PG-B6a and PG-B6p recognize, respectively, a highly conserved and a formol-resistant epitope on the human BCL-6 protein amino-terminal region. Am J Pathol 148: 1543-1555, 1996.

18 McIntosh GG, Lodge AJ, Watson P, Hall AG, Wood K, Anderson JJ, Angus B, Horne CHW, Milton ID: NCL-CD10-270: a new monoclonal antibody recognizing CD10 in paraffin-embedded tissue. Am J Pathol 154: 77-82, 1999.

19 Ree HJ, Yang WI, Kim CW, Huh J, Lee SS, Cho EY, Ko YH, Charney D : Coexpression of Bcl-6 and $\mathrm{CD} 10$ in diffuse large B-cell lymphomas: significance of Bcl-6 expression patterns in identifying germinal center B-cell lymphoma. Hum Pathol 32 : 954-962, 2001.

20 Huang JZ, Sanger WG, Greiner TC, Staudt LM, Weisenburger DD, Pickering DL, Lynch JC, Armitage JO, Warnke RA, Alizadeh AA, Lossos IS, Levy R, Chan WC: The $t(14 ; 18)$ defines a unique subset of diffuse large B-cell lymphoma with a germinal center B-cell gene expression profile. Blood 99 : 2285-2290, 2002.
21 McCluggage WG, Catherwood M, Alexander HD, McBride HA, Smith MEF, Morris TCM : Immunohistochemical expression of CD10 and $t(14 ; 18)$ chromosomal translocation may be indicators of follicle centre cell origin in nodal diffuse large B-cell lymphoma. Histopathology 41: 414-420, 2002.

22 Ballesteros E, Osborne BM, Matshushima AY: $\mathrm{CD}^{+}$low-grade marginal zone B-cell lymphomas with localized presentation. Am J Surg Pathol 22 : 201-207, 1998.

23 Millar EKA, Waldron S, Spencer A, Braye S: CD10 positive thyroid marginal zone non-Hodgkin's lymphoma. J Clin Pathol 52: 849$850,1999$.

24 Kwon MS, Go JH, Choi JS, Lee SS, Ko YH, Rhee JC, Ree HJ : Critical evaluation of Bcl-6 protein expression in diffuse large B-cell lymphoma of the stomach and small intestine. Am J Surg Pathol 27 : 790-798, 2003.

$25 \mathrm{Xu} \mathrm{Y,} \mathrm{McKenna} \mathrm{RW,} \mathrm{Kroft} \mathrm{SH} \mathrm{:} \mathrm{Assessment} \mathrm{of}$ CD10 in the diagnosis of small B-cell lymphomas: a multiparameter flow cytometric study. Am J Clin Pathol 117: 291-300, 2002.

26 Kaleem Z, White G, Vollmer RT : Critical analysis and diagnostic usefulness of limited immunophenotyping of B-cell non-Hodgkin's lymphomas by flow cytometry. Am J Clin Pathol 115: 136-142, 2001.

27 Omonishi K, Yoshino T, Sakuma I, Kobayashi K, Moriyama M, Akagi T : Bcl-6 protein is identified in high-grade but not low-grade mucosa-associated lymphoid tissue lymphomas of the stomach. Mod Pathol 11: 181-185, 1998.

28 Gaidano G, Capello D, Gloghini A, Fassone L, Vivenza D, Ariatti C, Migliazza A, Saglio G, Carbone A: Frequent mutation of bcl-6 protooncogene in high grade, but not low grade, MALT lymphomas of the gastrointestinal tract. Haematologica 84: 582-588, 1999.

29 De Wolf-Peeters C, Achten R: The histogenesis of large-cell gastric lymphomas. Histopathology 34 : 71-75, 1999.

30 Hans CP, Weisenburger DD, Greiner TC, Gascoyne RD, Delabie J, Ott G, Muller-Hermelink HK, Campo E, Braziel RM, Jaffe ES, Pan Z, Farinha P, Smith LM, Falini B, Banham AH, Rosenwald A, Staudt LM, Connors JM, Armitage JO, Chan WC : Confirmation of the molecular classification of diffuse large B-cell lymphoma by immunohistochemistry using a tissue microarray. Blood 103 : 275-282, 2004.

31 Ashton-Key M, Biddolph SC, Stein H, Gatter KC, Mason DY: Heterogeneity of bcl-2 expression in MALT lymphoma. Histopathology 26: 75-78, 
1995.

32 Villuendas R, Piris MA, Orradre JL, Mollejo M, Rodriguez R, Morente $\mathrm{M}$ : Different $b c l-2$ protein expression in high-grade B-cell lymphomas derived from lymph node or mucosa-associated lymphoid tissue. Am J Pathol 139: 989-993, 1991.

33 Du MQ, Singh N, Husseuin A, Isaacson PG, Pan L : Positive correlation between apoptotic and proliferative indices in gastrointestinal lymphomas of mucosa-associated lymphoid tissue (MALT). J Pathol 178: 379-384, 1996.

34 Nakamura S, Akazawa K, Kinukawa N, Yao T, Tsuneyoshi $\mathrm{M}$ : Inverse correlation between the expression of $\mathrm{bcl}-2$ and $\mathrm{p} 53$ proteins in primary gastric lymphoma. Hum Pathol 27 : 225-233, 1996.

35 Navratil E, Gaulard P, Kanavaros P, Audouin J, Bougaran J, Martin N, Diebold J, Mason DY: Expression of the bcl-2 protein in B cell lymphomas arising from mucosa associated lymphoid tissue. J Clin Pathol 48: 18-21, 1995.

36 Jans DA, Sutton VR, Jans P, Froelich CJ, Trapani JA : BCL-2 blocks perforin-induced nuclear translocation of granzymes concomitant with protection against nuclear events of apoptosis. J Biol Chem 274 : 3953-3961, 1999.

37 Wotherspoon AC, Doglioni C, Diss TC, Pan L, Moschini A, de Boni M, Isaacson PG : Regression of primary low-grade B-cell gastric lymphoma of mucosa-associated lymphoid tissue type after eradication of Helicobacter pylori. Lancet 342 : 575-577, 1993.

38 Zucca E, Roggero E: Biology and treatment of MALT lymphoma: the state-of-the-art in 1996. Ann Oncol 7: 787-792, 1996.

39 Qin Y, Greiner A, Hallas C, Haedicke W, MullerHermelink HK : Intraclonal offspring expansion of gastric low-grade MALT-type lymphoma: Evidence for the role of antigen-driven high-affinity mutation in lymphomagenesis. Lab Invest $76: 477-$ 485, 1997.

40 Essop MF, Blakolmer K, Close PM, Manuel YE, Cornelius S: Analysis of low and high grade B-cell lymphoma subtypes using semi-nested PCR and two primer sets. Eur J Haematol 59: 136-141, 1997.

41 Hoshida Y, Kusakabe H, Furukawa H, Kasugai T, Miwa H, Ishiguro S, Aozasa K : Reassessment of gastric lymphoma in light of the concept of mucosaassociated lymphoid tissue lymphoma. Analysis of 53 patients. Cancer 80: 1151-1159, 1997.

42 Maes B, De Wolf-Peeters C: Marginal zone cell lymphoma - an update on recent advances. Histopathology $40: 117-126,2002$.
43 Eshoa C, Perkins S, Kampalath B, Shidham V, Juckett M, Chang CC: Decreased CD10 expression in grade III and in interfollicular infiltrates of follicular lymphomas. Am J Clin Pathol 115: 862$867,2001$.

44 Uherova P, Ross CW, Schnitzer B, Singleton TP, Finn WG: The clinical significance of CD10 antigen expression in diffuse large B cell lymphoma. Am J Clin Pathol 115: 582-588, 2001.

45 Takeshita M, Iwashita A, Kurihara K, Ikejiri K, Higashi $\mathrm{H}$, Udoh $\mathrm{T}$, Kikuchi $\mathrm{M}$ : Histologic and immunohistologic findings and prognosis of 40 cases of gastric large B-cell lymphoma. Am J Surg Pathol 24: 1641-1649, 2000.

46 Chang CC, McClintock S, Cleveland RP, Trzpuc T, Vesole DH, Logan B, Kajdacsy-Balla A, Perkins SL: Immunohistochemical expression patterns of germinal center and activation B-cell markers correlate with prognosis in diffuse large B-cell lymphoma. Am J Surg Pathol 28: 464-470, 2004.

47 Natkunam Y, Warnke RA, Montgomery BA, Falini B, van de Rijn M: Analysis of MUMl/IRF4 protein expression using tissue microarrays and immunohistochemistry. Mod Pathol 14: 686-694, 2001.

48 Go JH, Yang WI, Ree HJ : Mutational analysis of the 5 ' noncoding region of the Bcl-6 gene in primary gastric lymphomas. Mod Pathol 14 : 410-414, 2001.

49 Meda BA, Frost M, Newell J, Bohling SD, Huebner-Chan DR, Perkins SL, Lim MS, Medeiros LJ, Elenitoba-Johnson KSJ : BCL-2 is consistently expressed in hyperplastic marginal zones of the spleen, abdominal lymph nodes, and ileal lymphoid tissue. Am J Surg Pathol 27 : 888-894, 2003.

50 Gisbertz IAM, Schouten HC, Bot FJ, Arends J-W : Proliferation and apoptosis in primary gastric B-cell non-Hodgkin's lymphoma. Histopathology 30 : 152-159, 1997.

51 Stefanaki K, Tzardi M, Kouvidou CH, Chaniotis V, Bolioti M, Vlychou M, Zois M, Kakolyris S, Delides G, Rontogianni D, Georgoulias V, Kanavaros P: Expression of p53, p21, mdm2, Rb, bax and Ki67 proteins in lymphomas of the mucosaassociated lymphoid (MALT) tissue. Anticancer Res 18: 2403-2408, 1998.

52 Piris MA, Pezella F, Martinez-Montero JC, Orradre JL, Villuendas R, Sanchez-Beato M, Cuena R, Cruz MA, Martinez B, Garrido MC, Gatter K, Aiello A, Delia D, Giardini R, Rilke F: p53 and bcl-2 expression in high-grade B-cell lymphomas : correlation with survival time. Br J Cancer 69: 337-341, 1994. 